\title{
THE DEVELOPMENT OF SHOE DESIGN AND FOOTWEAR SECTOR IN BULGARIAN GEOGRAPHY FROM THE PRE-MILESTONE PERIODS TO THE PRESENT
}

\section{Sevim YILMAZ*}

Pamukkale University, Denizli Technical Vocational School of Higher Education, Denizli, Turkey, e-mail: sevimy@pau.edu.tr

Received: 27.12 .2018

Accepted: 24.03.2019

https://doi.org/10.24264/Ifj.19.1.7

THE DEVELOPMENT OF SHOE DESIGN AND FOOTWEAR SECTOR IN BULGARIAN GEOGRAPHY FROM THE PRE-MILESTONE PERIODS TO THE PRESENT

ABSTRACT. The footwear has an important role in human life from the past to the present due to its ability to protect the human foot and provide comfortable walking. In time, different nations have created their own national shoes, and these national shoes have varied and changed in accordance with the relevant climate and geographic conditions. In the Bulgarian people, the production of its own shoes has gained momentum since the 17th century. Footwear industry in Bulgaria was been formed as sector and good developed due to time of national government from 1947-1980 years. Then after the revolution in 1990 year the factories were privatized. The aim of this study is to investigate the structure of shoes designed in Bulgarian geography in terms of aesthetics and comfort in the historical process and the status of the shoe industry since 2000s to the present.

KEY WORDS: footwear design, Bulgarian footwear industry

DEZVOLTAREA SECTORULUI DE PROIECTARE ȘI FABRICARE A ÎNCĂLṬĂMINTEI ÎN SPAȚIUL GEOGRAFIC AL BULGARIEI DIN PERIOADA PREISTORICĂ PÂNĂ ÎN PREZENT

REZUMAT. Din trecut până în prezent, încălțămintea a jucat un rol important în viața omului datorită abilității acesteia de a proteja piciorul și de a oferi confort în timpul mersului. În timp, diferite națiuni și-au creat propriile modele specifice de încălțăminte, acestea variind și schimbându-se în funcție de condițiile climatice și geografice relevante. La poporul bulgar, producția de încălțăminte proprie a luat avânt încă din secolul al XVII-lea. Industria de încălțăminte din Bulgaria a luat naștere ca sector și s-a dezvoltat sub guvernul național în perioada 19471980. Apoi după revoluția din anul 1990, fabricile s-au privatizat. Scopul acestui studiu este de a investiga structura încălțămintei proiectate în spațiul geografic bulgar în ceea ce privește estetica și confortul în procesul istoric și statutul industriei de încălțăminte din anii 2000 până în prezent.

CUVINTE CHEIE: designul încălțămintei, industria de încălțăminte din Bulgaria

\section{LE DÉVELOPPEMENT DU SECTEUR DE LA CONCEPTION ET LA FABRICATION DE LA CHAUSSURE DANS LA RÉGION GÉOGRAPHIQUE DE LA} BULGARIE DE LA PÉRIODE PRÉHISTORIQUE JUSQU'À PRÉSENT

RÉSUMÉ. Du passé au présent, la chaussure a joué un rôle important dans la vie humaine en raison de sa capacité à protéger le pied et à offrir un confort pendant la marche. Au fil du temps, les différentes nations ont créé leurs propres modèles de chaussures, et ces modèles de chaussures nationales ont varié et ont changé en fonction des conditions climatiques et géographiques pertinentes. Chez le peuple bulgare, la production de ses propres chaussures a pris de l'ampleur depuis le XVIle siècle. Le secteur de la chaussure en Bulgarie est né en tant que secteur et s'est développé sous le gouvernement national de 1947 à 1980. Après la révolution de 1990, les usines ont été privatisées. L'objectif de cette étude est d'étudier la structure des chaussures conçues dans l'espace géographique bulgare en termes d'esthétique et de confort dans le processus historique et le statut de l'industrie de la chaussure depuis les années 2000.

MOTS CLÉS : conception des chaussures, industrie de la chaussure bulgare

\footnotetext{
"Correspondence to: Sevim YILMAZ, Pamukkale University, Denizli Technical Vocational School of Higher Education, Denizli, Turkey, e-mail:
} sevimy@pau.edu.tr 


\section{INTRODUCTION}

With the development of human needs, the design of shoes responding to the aesthetic demands of human has been on the agenda. In the first era, the shoes meet the needs of human dressing and protection from cold, nowadays they respond to the search for aesthetics. Man has always acted in his life taking into account his health. This was reflected in the primitive shoe designs in the pre-milestone periods. Instead of shoes, the primitive people formed the soles from the barks or tree leaves and tied them with various fibers to their feet. Later on, people used skins of the killed animals to wrap their feet and tied them to their feet by thin leather ropes or muscle fibers. People, who succeeded in leather tanning as a result of various experiments over time, dyed the leathers by using red, purplish or other eye-catching colors in leather making. Such shoes were costly, and only the rulers or tribal leaders are known could afford them. Today, examples of these shoes are seen in archaeological museums.

The use of the footwear, its aesthetic aspect, and the materials used to emphasize the economic privilege, status, and reflection of the culture. The footwear strengthened its position as a garment through the historical period and took an active role in the designs [1].

In ancient Greece, Homer's heroes Iliad and Odyssey wore bronze sandals and gods wore sandals made of gold. At that time, both men and women were wearing sandals. These sandals were pinned on the foot with a leather band and the sole was cork.

As time passed, people discovered the leather making operations; the processed leather also showed a great effect on the structural development of the footwear. Cultural and technological development of the society, traditions and aesthetic expectations of the community, geographic climatic conditions showed a similar effect [2].

In time, different nations have created their own national shoes, and these national shoes have varied and changed in accordance with the relevant climate and geographic conditions. Therefore, one aim of this study is to examine the aesthetics and comfort of the shoes in the Bulgarian geography.

\section{THE DEVELOPMENT OF FOOTWEAR PRODUCTION IN BULGARIAN GEOGRAPHY}

Reliable data from the nearest periods are available about Thracians. The leaders of the communities used to wear individual shoes on both legs. Both shoes have separate soles (Figure $1 \mathrm{c}$ ). It has worked on three different structures. The sandals belonged to women and the clothes carried by women were covered, soft home shoes, boots as high-heeled winter shoes were known. After the ancient Thracians, Greeks and Romans wore such asymmetrical shoes with the different right and left pairs. This is a demonstration of the high culture of those nations. Careful handling of these shoes is proof of the aesthetic value given to the shoes by the nations [3].

In some excavations, shoes with gilt and stitched shoes from the 3rd century BC were found. These shoes were found in the tombs of the Thracians. The image of the shoe made on a ring of that period constitutes evidence for the aesthetic approaches of the Thracians to shoes.

It is said that the production of shoes and slippers was accepted in the cities of Stara Zagora, Karlovo and Tarnovo in the 1600 s as the beginning of the shoe craft. These shoes are of the type where the upper parts of the shoes are attached to the soles by stitching. The main users of these shoes were the Turkish people living in the area. They called them in Arabic terms: "Imenii" and "Kalevri". It is estimated that they were transported by Turks from Middle Asia during their migration on the Balkan Peninsula. Later in Bulgaria, shoes were bought and sold by traders from Vienna, Bucharest, and Istanbul, and these are the shoes without the front ridge, attached to the base with the wooden nails, which were called brogan. The craftsmen 
who produce these shoes have also begun to be called cobbler or shoemakers. Shoemakers have privileged among the administrators of the state and have more rights. At that time leather shoes (galoshes) which were worn on the winter shoes were produced. These galoshes were manufactured according to the form of the other shoes and were attached to the other shoes with wooden nails during the fall period. Dry intestines were placed between two shoe layers to prevent water from passing [2]. It is understood that in the $21^{\text {st }}$ century Bulgarian researchers contributed to the clothing industry more 300 years ago with subjective methods regarding the humidity and heat comfort, and shoe designs were made taking into account the health and comfort of the human.

With the arrival of the Slavs in this territory, "Balkan charik" have found a wide area of use. This type of shoes was widely used by the villagers until the 1930s. One of the wearers of the "Balkan charik" was Ömer Seyfettin, one of the authors of the Constitutional monarchy of the Ottoman Empire. In the article of Mehmet Güneş for him it was written that "He passed the time during the day following the Bulgarian commissioners on the mountains with the Mauser in his hands, cartridge cross-belt on his chest and with the "Charics" on his feet; nights spending in khans or at the border police stations reading and writing letters to his friends in the light of oil lamps or fires [4].

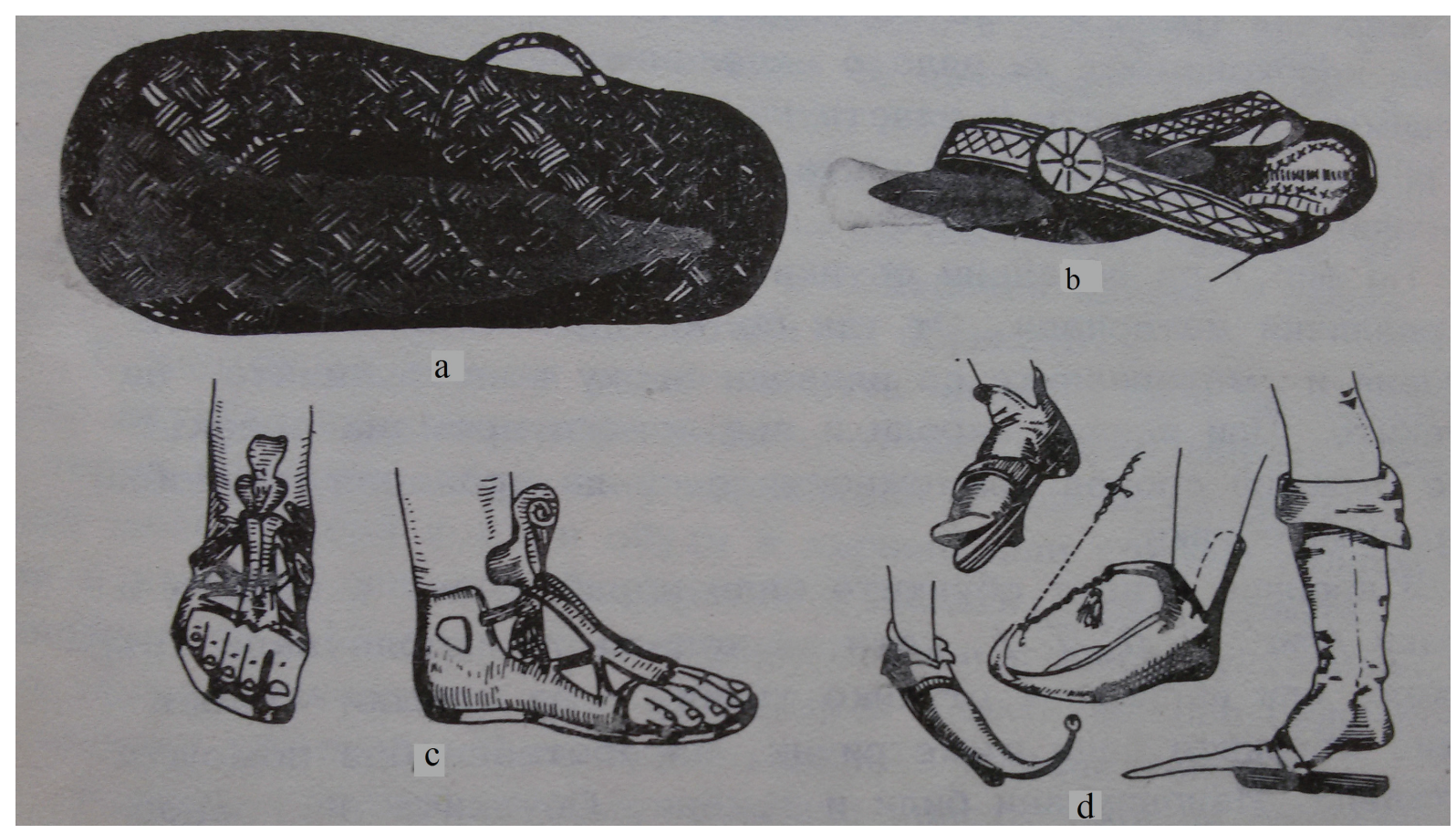

Figure 1. Shoe Models of the Ancient Times: a) Egyptian sandal (BC XIII century), b) Egyptian boat (III century BC), c) Asymmetric Thracian shoe, d) Medieval shoes [3]

The cheap cost of the "Charik" and fit sizes of them have been an example for the production of similar ones nowadays. On the Figure 2 was shown a photograph taken in the 1936 year of Bulgarian Turkish man named Arif Omer Ali, who was "Charik" master and was living in Bulgarian "Ludogorie" region. The shoes which can be seen worn on his foot are chariks, which he made by traditional techniques known by his ancestors. The "Charik" is produced from one piece of the leather and processed with a slight lifting of the front, which allows the fingers to move freely. Due to the curves in the nose and the heel of the shoe, the feet are firmly placed on the soles of the shoe, and as the body balance and the weight are evenly distributed, the soles 
are rubbing evenly. Thus, the sole is stepped more widely. The pressure in the equal areas of the foot is balanced. Thanks to the straps and strings to tighten, the shoe fits nicely on the foot, reducing friction on the sole of the shoe. These three rational elements provide the structural characteristics of today's footwear processing. Achieving a suitable twist in the heel part has only become possible in the last 1980s. Thus, new shoes in a form similar to the sole of the "Charik" are designed.

After the formation of the Bulgarian State, the Khans and the leaders carried various kinds of ornamented, colourful and glittering shoes in accordance with the traditions remaining from Thracians and the Roman examples. With the development of different arts and handicrafts, the city master started to wear similar shoes suitable for that period. When the Balkan peoples connected to the Ottoman Empire escaped from being a principality and turned into new governments after the First World War, the production of shoes and handicrafts have been developed in the form of customized production.

After the 1900s, two types of shoemaking in Bulgaria are developing, and these are based on handcraft or manual products and

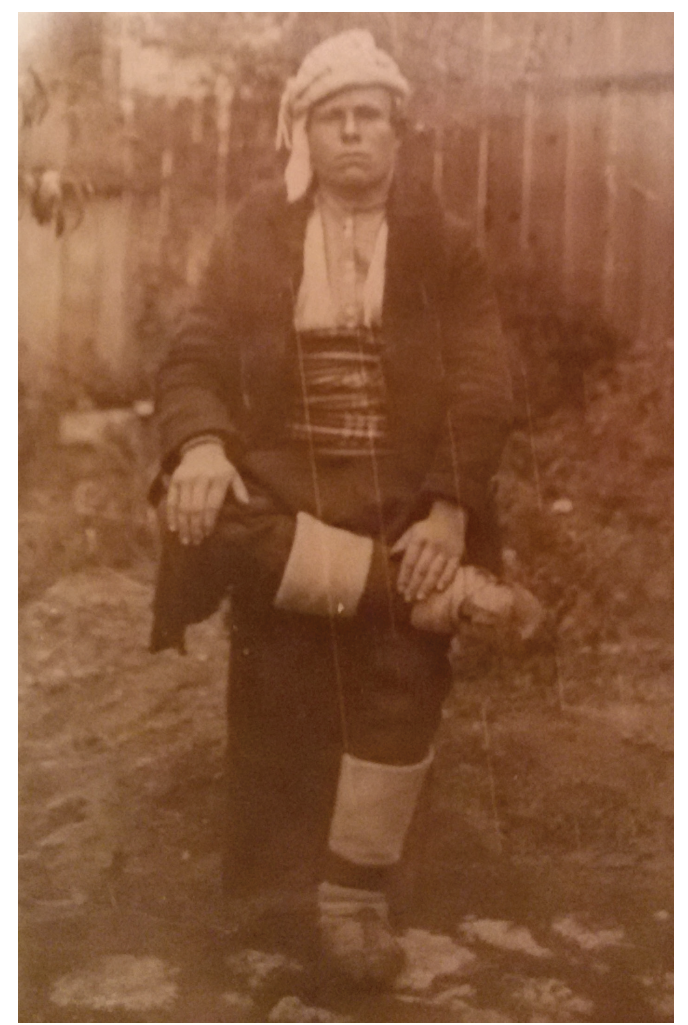

Figure 2. Photograph of Bulgarian Charik Master Arif Ömer Ali with "Chariks" on His Foot manufacture by factories. This period was called capitalism and the first fabrication production began in 1908 in the enterprises named Yantra and Progres established in the Gabrovo town. After the Second World War, the socialist republic, which was established in Bulgaria, seized and nationalized all private enterprises (making it the property of all the public).

Footwear industry in Bulgaria was been formed as sector and good developed due to time of national government. In 1947 year were nationalised 18 small manufactories and developed. In 1952 all footwear production were concentrated in 3 big production factories [5]. New craft cooperatives have been organized. The largest cooperative named "Deveti Septemvri" ( $9^{\text {th }}$ September) was founded in Sofia. Later, large governmental factories were established in Sofia, Filibe (Plovdiv) and Gabrovo [2]. These footwear enterprises were enlarged and reorganized with engineering-based studies and the production areas were leather shoes with the rubber soles and semi-fabricated products. From 1960 to 1980 years was been done plane reconstruction of production forces and was been put into practice current technologies with high productive machinery. The main aim of the socialist republic was to offer a comfortable life for the working class and to form and maintain the existence of the republic by prioritizing their health. As a result of this policy from 1947 to 1990, the number of shoe varieties suitable for large masses was low but ergonomic, healthy shoes with leather upper, standardized according to the anatomical foot structure of the people were produced and used.

My visits to Bulgaria from the 2000s and my observations on the garment sector are very challenging. After the forced migration of a large part of the Turkish population to Turkey in 1989, the collapsed economy in Bulgaria has experienced the second decline since the companies have been relayed for the third time in 2010s and mainly sold to European investors with the scrap prices. In 2010-2013, it was seen from the university visits and training made in the scope of Erasmus Program in Bulgaria that the leather and textile productions were decreased very much and the production of footwear was almost not in the good situation [6]. The main reason for this is that the people migrated to other developed countries in the 
European Union to find a job and the purchasing power of the consumers in the local market is addressed by cheap and mostly artificial leather shoes from China [6].

In the national governmental period, the development of footwear in the light industry branches in Bulgaria has also been seriously improved in the context of engineering education, while the present situation is very thought-provoking for Bulgaria.

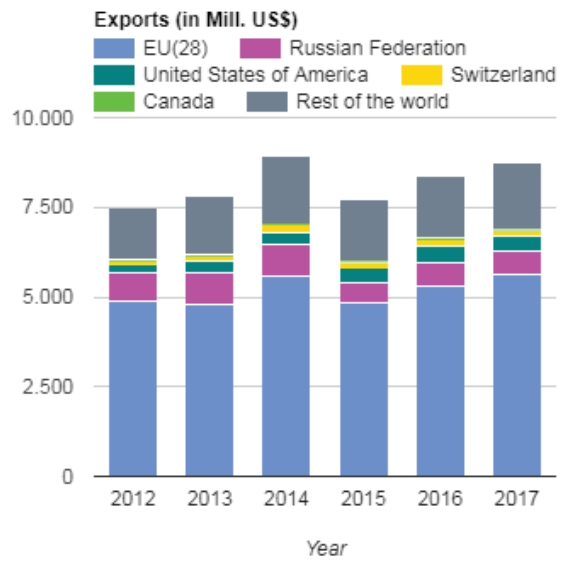

\section{FOOTWEAR PRODUCTION IN BULGARIAN IN} LAST 5 YEARS

The latest data for footwear was been taken from WTO-UNCTAD-ITC trade in services database, based on OECD, IMF, EUROSTAT, UNSD, and national data, (Commercial services trade, balance of payments based statistics, June 2018). As can be seen at graph charts in Figure 3. for export and import, the Bulgarian economy has small grown of the years between 20121013 and good growth in 2015. In 2015 years all off trade with word biggest countries like Russia, China and E.U. were decreased; only trade with Switzerland increased. Then in 2016 and 2017 years export and import volumes of Bulgarian economy are increased.

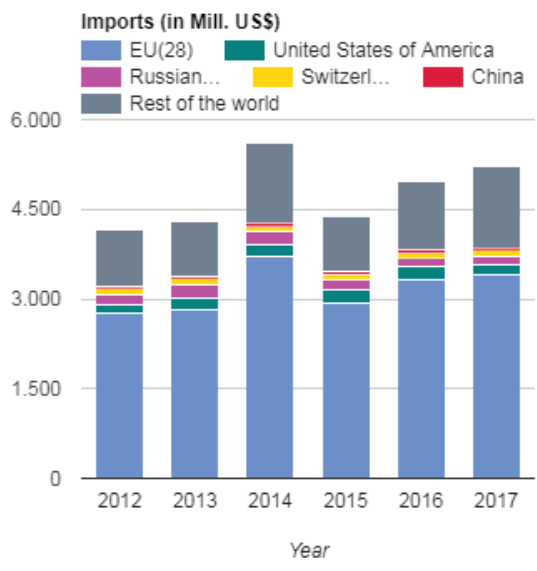

Figure 3. Export And Import Levels of Bulgaria Between 2012-2017 Years [7]

Table 1 shows the situation of export for "Footwear, Gaiters And The Like; Parts Of Such Articles" [8]. For footwear, gaiters and the like products situation was similar to the general economic situation of the Bulgarian economy between 2013-2017 years period. According to trademap.org the export of "Footwear, Gaiters And The Like" from Bulgaria in the 2014 year increased by $21250000 \$$ and 8,1\% than in the 2015 year decreased $47330000 \$$ and $16,7 \%$. In 2016 year decreased $11456000 \$$ and \% 4,85. In 2017 increased by 9070000 and $4 \%$ but just it is lower than the export value of the 2014 year.

\section{CONCLUSION AND RECOMMENDATIONS}

From the 17th century to the present day, it is seen that in Bulgaria are produced shoes, suitable for the anatomical foot structure of the people and aesthetics in the design as well as comfort was at the forefront. And also, the footwear has been an indicator of social status throughout history. Generally, the more the economic level of people increases, the more the number and type of shoes they use are increased. Today's globalization conditions have also led to serious changes in the economic structures and business areas of countries. In that, production in all industrial areas including handicrafts and shoemaking in Bulgaria has been declined considerably. It would not be wrong to say that for the last 10 years Bulgaria has been impoverished and transformed into a state of tourism and retirees. It is a painful fact to mention that the population residing in Bulgaria in the last 30 years has fallen by half. Policies should be developed to generate employment by taking into consideration not only the EU's main objectives and incentive policies for production sites but also the areas where Bulgaria has a trained workforce. In the 
Table 1: The Exported Footwear Value of Some Main Producer Countries and Bulgaria Between 20132017 Years [8]

\begin{tabular}{cccccc}
\hline Exporters & $\begin{array}{c}\text { Exported value in } \\
\text { 2013 }(1000 \$)\end{array}$ & $\begin{array}{c}\text { Exported value in } \\
2014(1000 \$)\end{array}$ & $\begin{array}{c}\text { Exported value in } \\
2015(1000 \$)\end{array}$ & $\begin{array}{c}\text { Exported value in } \\
2016(1000 \$)\end{array}$ & $\begin{array}{c}\text { Exported value in } \\
2017(1000 \$)\end{array}$ \\
\hline World & 128949458 & 141843403 & 133803512 & 130191067 & 144385644 \\
China & 50761328 & 56248574 & 53509469 & 47202913 & 48185818 \\
Viet Nam & 8721913 & 10690489 & 12438847 & 13476379 & 20767911 \\
Italy & 11788762 & 12290849 & 10494224 & 10707969 & 11315309 \\
Germany & 5137252 & 5815306 & 5231008 & 6036408 & 7614737 \\
Belgium & 5130632 & 5584602 & 5415641 & 5967638 & 6591733 \\
Indonesia & 3860394 & 4108448 & 4507024 & 4639859 & 4911848 \\
France & 2933247 & 3215640 & 3172570 & 3396740 & 3700207 \\
Netherlands & 3416248 & 3623613 & 3048115 & 3263366 & 3426153 \\
Spain & 3148885 & 3689282 & 3420928 & 3089709 & 3187520 \\
Hong Kong, China & 4688789 & 4341253 & 3916437 & 3139030 & 2901176 \\
India & 2609804 & 2990733 & 2771020 & 2747900 & 2785993 \\
Portugal & 2361753 & 2523549 & 2117759 & 2178049 & 2271471 \\
United Kingdom & 1899789 & 2104166 & 2211092 & 2161956 & 2160210 \\
Austria & 980745 & 1067987 & 893279 & 843707 & 871977 \\
Romania & 1771201 & 1879864 & 1463504 & 1448138 & 1523998 \\
Poland & 940700 & 1023193 & 1046558 & 1211561 & 1487886 \\
Brazil & 1391432 & 1455212 & 1463618 & 1367459 & 1432136 \\
Slovakia & 1263257 & 1237604 & 1114316 & 1164794 & 1278009 \\
Czech Republic & 1261681 & 1369904 & 1137422 & 1079202 & 1155788 \\
Panama & 817241 & 894321 & 818747 & 907174 & 1107073 \\
Bulgaria & 1135091 & 1120121 & 971026 & 864894 & 67909 \\
United States of America & 262176 & 283426 & 236096 & 224640 & 233710 \\
\hline
\end{tabular}

Bulgarian parliament, incentives should be raised in order to revitalize the footwear sector, which is a branch of the apparel industry, and to generate the production of footwear for the needs of the local population; and by creating employment in this sector to support the prevention of the migration of the Bulgarian people. For the country with the present academic staff and with more know-how in this area than in many producer countries such as China, Thailand or Turkey, increasing the country's budget for education and academic studies will be in the benefit of its people in the long term.

\section{REFERENCES}

1. Ýmre, H.M., Tarihsel Gelişim Ýçerisinde Ýnsan, Moda, Ayakkabý Ýliţkisi, International Journal of Cultural and Social Studies (IntJCSS), 2016, August, 2(SI 1): 189-204.

2. Jifkova, L., Bojankova, C., Tcvetkov, P., Dyankov, Ý., Tehnologiya Na Obuvnoto Proizvodstvo (Ayakkabý Üretim Teknolojisi), Sofia, 1975.

3. Tcvetkov, P., Tehnologiya na obuvnoto $i$ galanteriynoto proizvodstvo" (Ayakkabi ve Sarraciye Üretim Teknolojisi), Sofia, 1982.

4. Güneş, M., XX. Yüzyýlýn Baţlarýnda Balkanlardaki Siyasi ve Etnik Çatýţmalarýn
Ömer Seyfettin'in Hikayelerine Yansýmasý TÜBAR-XXIX, 2011, Bahar, 163-185.

5. Vasilev, E.S., Gadjanov S.Y. et al., Narichnic Za Obuvnata Promishlenost, Dirjavno Izdatelstvo "Technika", Sofia, 1990.

6. Yýlmaz, S., Bayramoðlu, E.E., The Importance of the Foot Anatomy in Shoe Design in Balkans Geography in Pre-Milestone Periods to Nowadays, $5^{\text {th }}$ ASM International Congress of Social Science, 3-5 May 2018, Antalya, Turkey, Proceeding Book.

7. $\quad$ http://itip.wto.org/services/GATS_ Detail.aspx/?id=Bulgaria\&sector path=Horizontal\&rta_path $=0$ 000(Date: 04.11.2018)

8. Footwear, Gaiters and the Like; Parts of such Articles, accessed 04.11.2018, available at: https://www.trademap.org.

(C) 2019 by the author(s). Published by INCDTPICPI, Bucharest, RO. This is an open access article distributed under the terms and conditions of the Creative Commons Attribution license (http://creativecommons.org/licenses/by/4.0/). 